\title{
Analysis of macro- and Microminerals Content in the Einkorn (Triticum monococcum L.) Samples Cultivated in Kastamonu, Turkey
}

\author{
Şeref Turhan",a,*, Aslı Kurnaz ${ }^{1, b}$ \\ ${ }^{1}$ Faculty of Science and Letters Kastamonu University, 37150 Kastamonu, Turkey \\ *Corresponding author \\ A R T I C L E IN F O A B S T R A C T \\ Research Article \\ Wheat is an important cereal product because of its nutritional value, economy, culture, and history. \\ Einkorn (Triticum monococcum L.) assumed as the oldest wheat. Einkorn locally called "siyez" has \\ recently become popular as a super grain with the thought of being very nutritious in Turkey. In this \\ study, the contents of macrominerals ( $\mathrm{Na}, \mathrm{Mg}, \mathrm{Ca}$, and $\mathrm{K}$ ) and microminerals $(\mathrm{Cr}, \mathrm{Cu}, \mathrm{Fe}, \mathrm{Mn}$ and \\ Received : 09/02/2021 \\ Accepted : 07/04/2021 \\ $\mathrm{Zn}$ ) in twenty-one einkorn samples collected from different cultivation areas in Kastamonu were \\ determined by using an inductively coupled plasma-optical emission spectrometry following \\ microwave-assisted acid digestion. The results were compared with those analyzed in einkorn and \\ other wheat types in the literature. Average concentrations of $\mathrm{K}, \mathrm{Ca}, \mathrm{Mg}, \mathrm{Na}, \mathrm{Fe}, \mathrm{Zn}, \mathrm{Mn}, \mathrm{Cr}$ and $\mathrm{Cu}$ \\ analyzed in einkorn samples were found as 3712, 1303, 656, 53, 167, 34, 29, 0,7 and 0,6 mg kg-1, \\ respectively. The literature comparison revealed that the investigated einkorn samples were richer \\ Keywords: \\ Einkorn \\ in terms of $\mathrm{Ca}$ and Fe contents compared to einkorn, emmer, spelt, buckwheat, and durum wheat \\ Macrominerals \\ samples grown in our country and different countries. \\ Microminerals \\ Siyez \\ ICP-OES
}

serefturhan63@gmail.com (iD) https://orcid.org/0000-0001-5303-3680

|'@akurnaz@kastamonu.edu.tr

(D) https://orcid.org/0000-0002-7910-3461

(c) (1) \& This work is licensed under Creative Commons Attribution 4.0 International License

\section{Introduction}

Cereals are known as edible grains or seeds that are the grass (Gramineae) family members (McKevith, 2004). Cereals and grain-based foods contain protein and minerals that are indispensable for the world population. Some cereals are essential foods both for direct human consumption and indirectly through animal feed since the beginning of civilization. The production of cereals is generally cheap. Grains are easily stored, transported, and do not spoil easily if kept dry. Cereals and derivatives (food products obtained from cereals) are an important food group in both developed/developing countries. Cereals and their products are a series of essential elements sources such as carbohydrates, protein, fiber, lipids, vitamins (E vitamin, some B vitamins) and sodium, potassium, calcium, magnesium, iron, zinc, selenium, etc. The increased interest in cereals and derivatives is due to their bioactive components and the potential benefits of regular consumption of cereals and cereal products (McKevith, 2004).

Wheat, rice, and corn are the most produced and consumed cereal products worldwide. Wheat and rice are the most important crops with more than fifty percent of world grain revenue (McKevith, 2004). Wheat, which constitutes $30 \%$ of the grain production in the world, is the oldest known grain product that can be grown as both spring and winter food and therefore can be harvested at any time of the year (McKevith, 2004; Şenoğlu, 2019). Wheat, which has thousands of species, belongs to the Triticum family. Due to many wheat species and varieties and their easy adaptations, it is grown in many countries worldwide (more than 120 countries), under different climatic conditions and different environments, using different agricultural technologies or traditionally (Şenoğlu, 2019). Large parts of the wheat produced in Turkey as well as all over the world are used for human consumption. Due to its unique properties, a wide variety of ingredients and foods are produced from wheat, including wheat germ, couscous, shredded wheat, bulgur or cracked wheat, flour, and wheat starch. Wheat type Triticum Aestivum subspecies Vulgare and hard wheat Triticum durum is the most commercially important wheat type (McKevith, 2004).

Einkorn means "single grain" or "one seed" in German. Einkorn is the known oldest wheat type and its production date extends to approximately 12 thousand years (Sultan et 
al., 2020). Einkorn is among the diploid species of hulled wheat with $2 \mathrm{n}$ chromosome structure and its grains are tightly covered with their hard hulls (Emeksizoğlu, 2016). Einkorn wheat is known as Triticum boeoticum (wild wheat) or Triticum monococcum (domestic species) in taxonomy. Native and wild wheat forms can be considered as separate species or subspecies of Triticum monococcum. Einkorn (Triticum monococcum L.) is known with various names such as "siyez" and "kabulca" in Anatolia. Einkorn is accepted to be resistant to pests and diseases, as an extremely competitive species in poor soils and arid conditions since it has a single grain in its ears and its tight hull (Sultan et al., 2020). While einkorn cultivation was done more than a thousand years ago in Anatolia, today it is limited to only a few regions. A large part of einkorn (siyez) cultivation is done in İhsangazi districts of Kastamonu. The production of siyez wheat in Kastamonu province has increased linearly in the last five years. Siyez production (9110 tons) in 2018 increased by 6.2 times compared to 2014 siyez production (1472 tons). In the same way, the planting area of siyez in Kastamonu was 6690 decares in 2014 and reached 41409 decares in 2018 (Dalal et al., 2020). Siyez wheat boiled in hot water is dried under natural conditions and separated from its shells in water-operated mills in Kastamonu and its vicinity (Atak, 2017). Local people make use of siyez wheat as a "bulgur". Wheat stems are also a source of food for animals.

Minerals are essential for good health and growth. Certain amounts of minerals are needed to keep our bodies functioning properly. Minerals are defined as vital elements for the normal structure and functions of the body, except for $\mathrm{H}, \mathrm{C}, \mathrm{O}, \mathrm{N}$ and $\mathrm{S}$ which constitute the body's basic structure. Minerals with a daily requirement of more than $100 \mathrm{mg}$ are named as macrominerals ( $\mathrm{Na}, \mathrm{K}, \mathrm{Ca}, \mathrm{Mg}$, etc.) and minerals less than $100 \mathrm{mg}$ are named as microminerals or trace elements (Al, Ba, Fe, Zn, Mn, Sr, etc.) because their concentration in the body is very low. When not sufficiently taken, the elements that cause a dysfunction in the body and provide the correction of the related disorder as a result of physiological intake are known as essential elements. So far, several studies were published in the literature on the determination of elemental contents of wheat species (Abdel-Aal et al., 1995; Çakmak et al., 2000; Bâlint et al., 2001; Gabrovská et al., 2002; Løje et al., 2003; Özkan et al., 2007; Brandolini et al., 2008; Zhao et al., 2009; Erba et al., 2011; Suchowilska et al., 2012; Mutlu et. al., 2013; Mutlu and Uncumusaoğlu 2016; Kurnaz et. al., 2016; Mutlu et. al., 2016; Khan et al., 2017; Mutlu and Kurnaz, 2017; Zhang et al., 2018; Ertop and Atasoy, 2019; Mutlu, 2019). However, these studies are generally related to the human consumption and food preparation potential and there is no detailed study in the literature for determining the macro- and microminerals content of einkorn (siyez) samples. The purpose of this study is to complete the information missing in the literature by determining the levels of macrominerals ( $\mathrm{Na}, \mathrm{Mg}, \mathrm{Ca}$, and $\mathrm{K}$ ) and microminerals $(\mathrm{Cr}, \mathrm{Cu}, \mathrm{Fe}, \mathrm{Mn}$ and $\mathrm{Zn}$ ) in twenty-one einkorn (siyez) samples collected from different cultivation areas in Kastamonu were determined by using an inductively coupled plasma-optical emission spectrometry (ICP-OES) and compare those obtained in the literature.

\section{Material and Methods}

\section{Collection and Preparation of Sample}

Einkorn (siyez) samples were collected from twentyone different cultivation areas from the Ihsangazi district of Kastamonu province (Figure 1). Each siyez sample was extracted from their shells and coded to include information about the locations where they were collected. All samples were washed with water and then dried. The samples were homogenized by grinding in a sterile environment using a grinder (Isolab). Then, approximately $250 \mathrm{mg}$ of each siyez sample was inserted directly into a high-pressure laboratory microwave oven (Milestone Ethos 1600). Ten milliliters of $\mathrm{HNO}_{3}(67 \% \mathrm{v} / \mathrm{v})$ solution were added to each vessel. The heating program was carried out in two consecutive steps. Firstly, the temperature was linearly increased to $200^{\circ} \mathrm{C}$ in $15 \mathrm{~min}$. Secondly, the temperature was held at $200^{\circ} \mathrm{C}$ for $15 \mathrm{~min}$. After the digestion procedure the solutions were cooled to room temperature. Every digested sample was diluted with ultra-pure water. Also, blanks were prepared in each lot of siyez samples. All reagents used for analyses were of analytical grade.

Table 1. The operating parameters of the ICP-OES (Spectro Blue II)

\begin{tabular}{l|c}
\hline \multicolumn{1}{c|}{ Wavelength } & $\mathrm{nm}$ \\
\hline Replicates & 3 \\
Spray chamber & Cyclonic \\
Nebulizer flow $\left(\mathrm{L} \mathrm{min}^{-1}\right)$ & 0.8 \\
Plasma torc & Quartz \\
Coolant flow $\left(\mathrm{L} \mathrm{min}\right.$ m $\left.^{-1}\right)$ & 13 \\
Auxiliary gas flow $\left(\mathrm{L} \mathrm{min}\right.$ min $\left.^{-1}\right)$ & 0.8 \\
Sample pump speed (rpm) & 30 \\
Plasma power $(\mathrm{W})$ & 1200 \\
\hline
\end{tabular}

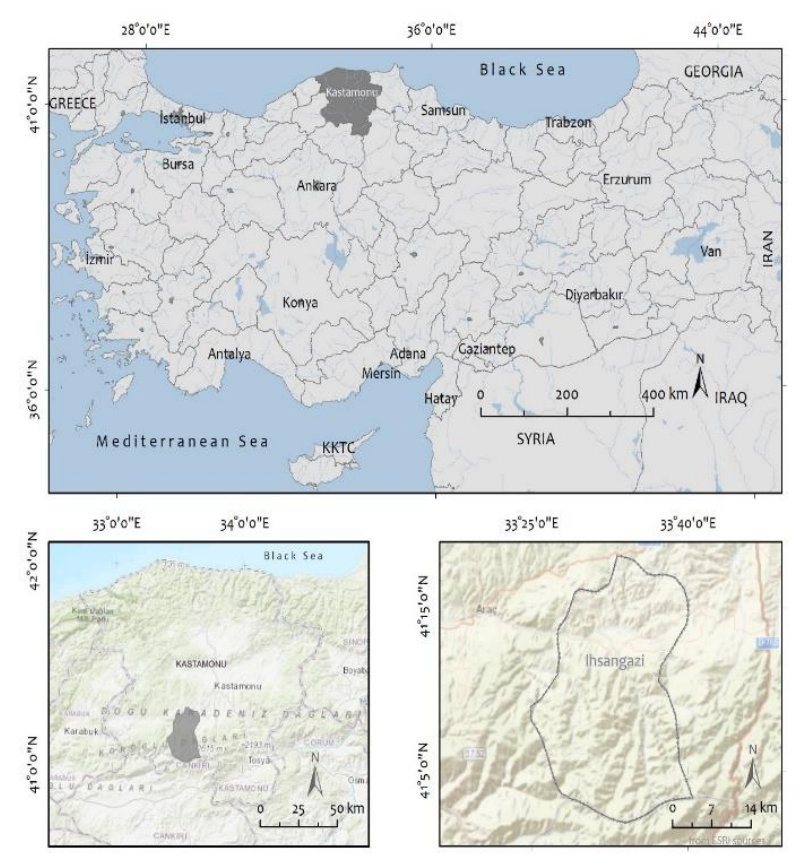

Figure 1. Location of İhsangazi district (Kastamonu, Turkey) 

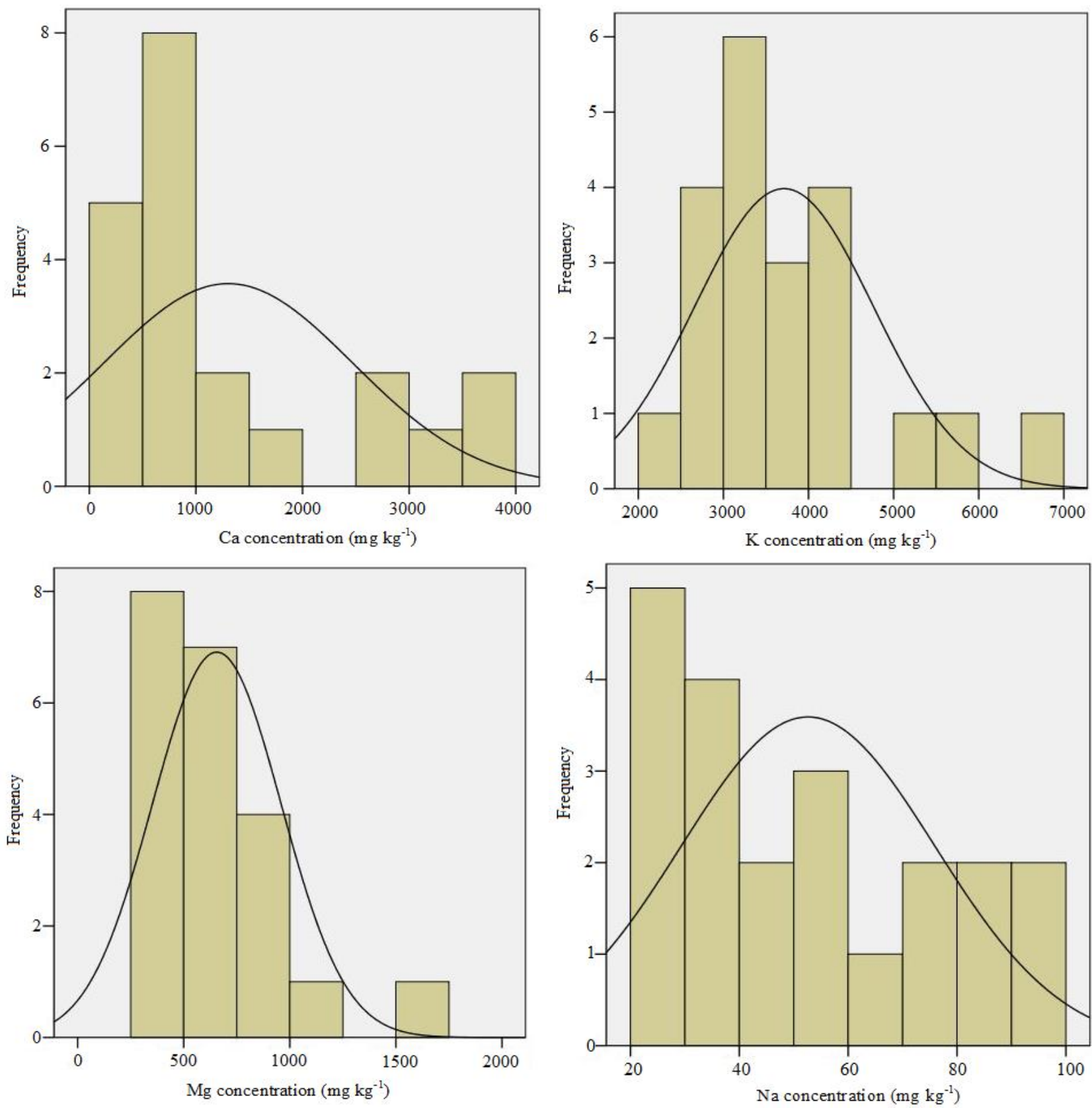

Figure 2. Concentration distribution of the macrominerals in siyez samples

\section{Analysis Procedure}

The analysis of macro-and microminerals were performed using an inductively coupled plasma-optical emission spectrometer (ICP-OES) with an axially viewed configuration (SPECTROBLUE II) equipped with Spectro's proprietary ICP Analyzer Pro software making it easy to take full advantage of the instrument's simplified operation and analytical capabilities. The operating conditions of the ICP-OES are given in Table 1. Calibration solutions were prepared by diluting the certified standard ICP multi-element standard solution IV of $1000 \mathrm{mg} \mathrm{L}^{-1}$ (23 elements in diluted nitric acid) purchased from Merck (Darmstadt, Germany). Calibration of the ICP-OES system was carried out at the beginning of the measurements and the correlation coefficients were equal to 0.999 for all analytes. The reading was made in triplicate.

\section{Results and Discussion}

The concentrations of macrominerals and microminerals analyzed in each siyez sample are given in Tables 2 and 3, respectively. The frequency distributions of macrominerals and microminerals are shown in Fig. 2. The comparisons of average concentrations of macrominerals and microminerals analyzed in the siyez samples with those analyzed in wheat species (einkorn, spelt, durum, emmer, and buckwheat) grown in some countries and Turkey are given in Tables 4 and 5, respectively.

As can be seen form Table 2, macrominerals are ranked as potassium $(\mathrm{K})>$ calcium $(\mathrm{Ca})>$ magnesium $(\mathrm{Mg})>$ sodium (Na) according to their average concentration values. $\mathrm{K}$ is essential element in in protein synthesis and activation of enzymes (Soetan et al., 2010). K helps in the proper function of brain and nerves and regulates acid-base 
and water balance in the blood and tissues (Adamu et al., 2016). The concentrations of $\mathrm{K}$ analyzed in the siyez samples varied from 2493 to $6571 \mathrm{mg} \mathrm{kg}^{-1}$ with an average of $3712 \mathrm{mg} \mathrm{kg}-1$. The highest concentration of $\mathrm{K}$ is analyzed in the Einkorn-4 while the lowest activity concentration is analyzed in the Einkorn-1. The concentration distribution of $\mathrm{K}$ exhibits log-normal distribution as shown in Fig. 2. $67 \%$ and $33 \%$ of $\mathrm{K}$ concentrations are between 2400 and $4000 \mathrm{mg} \mathrm{kg}^{-1}$ and 4200 and $6600 \mathrm{mg} \mathrm{kg}^{-1}$, respectively. From Table 3, the average $\mathrm{K}$ content of the siyez samples investigated is higher than the $\mathrm{K}$ content analyzed in emmer (Turkey) and spelt (Czech) while it is lower than the K content analyzed in einkorn (Poland, Czech, Canada and Belgium), emmer (Czech and Belgium), spelt (Canada), buckwheat, (Czech), durum (Turkey) and wheat (Belgium). $\mathrm{Ca}$ is the most abundant and important essential element in the human body. Ca plays important role in bones, teeth and muscles system and has key metabolic functions (Adamu et al., 2016). The concentrations of $\mathrm{Ca}$ analyzed in the siyez samples varied from 343 to $3669 \mathrm{mg} \mathrm{kg}^{-1}$ with an average of $1303 \mathrm{mg} \mathrm{kg}^{-1}$. The highest concentration of $\mathrm{Ca}$ is analyzed in the Einkorn-20 while the lowest activity concentration is analyzed in the Einkorn-2. The frequency distribution of $\mathrm{Ca}$ concentration exhibits a log-normal distribution. Approximately $71 \%$ of $\mathrm{Ca}$ concentrations are in the range of 340 to $1100 \mathrm{mg} \mathrm{kg}^{-1}$. The average Ca content of the siyez samples investigated is significantly higher than the $\mathrm{Ca}$ content analyzed in einkorn, emmer, spelt, buckwheat, durum and other wheat samples grown in different countries. $\mathrm{Mg}$ is an important essential element for all the cells in human body and present in many enzymes involved in lipids, proteins, and carbohydrate metabolism (Adamu et al., 2016). It activates more than 300 enzymes in the body (Abugoufa et al., 2020). The concentrations of $\mathrm{Mg}$ analyzed in the siyez samples varied from 369 to $1706 \mathrm{mg} \mathrm{kg}^{-1}$ with an average of $656 \mathrm{mg} \mathrm{kg}^{-1}$. The highest concentration of $\mathrm{Mg}$ is analyzed in the Einkorn-4 while the lowest activity concentration is analyzed in the Einkorn-18. The frequency distribution of $\mathrm{Mg}$ concentration exhibits a log-normal distribution. Approximately $91 \%$ of $\mathrm{Mg}$ concentrations are in the range of 350 to $950 \mathrm{mg} \mathrm{kg}^{-1}$. The average $\mathrm{Mg}$ content of the siyez samples investigated is higher than the $\mathrm{Mg}$ content analyzed in emmer (Turkey) while it is lower than those analyzed in einkorn, emmer, spelt, buckwheat, durum and other wheat samples grown in different countries. $\mathrm{Na}$ is an essential element for all living organisms (Adamu et al., 2016). Especially it is of great important for maintaining the balance of the fluid system and the work of nerves and muscles in the human body (Adamu et al., 2016). The concentrations of $\mathrm{Na}$ analyzed in the siyez samples varied from 28 to $97 \mathrm{mg} \mathrm{kg}^{-1}$ with an average of $53 \mathrm{mg} \mathrm{kg}^{-1}$. The highest concentration of $\mathrm{Na}$ is analyzed in the Einkorn-14 while the lowest activity concentration is analyzed in the Einkorn-2. The frequency distribution of Na concentration exhibits a non-normal distribution. Approximately $86 \%$ of $\mathrm{Na}$ concentrations are in the range of 25 to $85 \mathrm{mg} \mathrm{kg}^{-1}$. The average $\mathrm{Na}$ content of the siyez samples investigated is higher than the Na content analyzed in einkorn (Poland and Czech), spelt and buckwheat (Czech), durum (Turkey) and wheat (Belgium) while it is lower than the $\mathrm{Na}$ content analyzed in emmer (Czech and Belgium) and einkorn (Belgium).

Table 2. Concentrations of macrominerals in the einkorn (siyez)

\begin{tabular}{|c|c|c|c|c|}
\hline \multirow{2}{*}{ Sample code } & \multicolumn{4}{|c|}{ Concentration of macrominerals $\left(\mathrm{mg} \mathrm{kg}^{-1}\right)$} \\
\hline & $\mathrm{Na}$ & $\mathrm{Mg}$ & $\mathrm{Ca}$ & $\mathrm{K}$ \\
\hline Einkorn-1 & 57.1 & 520.0 & 2806.7 & 2493.0 \\
\hline Einkorn-2 & 27.7 & 538.7 & 343.1 & 3113.3 \\
\hline Einkorn-3 & 86.3 & 1009.1 & 590.9 & 5286.3 \\
\hline Einkorn-4 & 77.0 & 1706.1 & 3548.1 & 6571.2 \\
\hline Einkorn-5 & 52.6 & 581.7 & 373.3 & 3315.1 \\
\hline Einkorn-6 & 41.8 & 739.8 & 724.5 & 4139.4 \\
\hline Einkorn-7 & 38.2 & 603.9 & 542.5 & 3664.7 \\
\hline Einkorn-8 & 36.8 & 375.3 & 1063.2 & 2701.2 \\
\hline Einkorn-9 & 50.5 & 456.3 & 2809.9 & 3210.1 \\
\hline Einkorn-10 & 29.5 & 700.9 & 1537.2 & 4151.8 \\
\hline Einkorn-11 & 31.2 & 597.1 & 516.2 & 3578.7 \\
\hline Einkorn-12 & 29.8 & 835.3 & 449.9 & 4317.0 \\
\hline Einkorn-13 & 40.4 & 440.6 & 462.9 & 2721.9 \\
\hline Einkorn-14 & 96.5 & 895.5 & 3482.1 & 5625.2 \\
\hline Einkorn-15 & 29.7 & 382.5 & 942.5 & 3003.7 \\
\hline Einkorn-16 & 28.2 & 491.0 & 453.8 & 2954.3 \\
\hline Einkorn-17 & 64.7 & 818.1 & 638.4 & 4134.7 \\
\hline Einkorn-18 & 83.9 & 369.1 & 706.5 & 2769.3 \\
\hline Einkorn-19 & 72.8 & 431.9 & 645.9 & 3097.1 \\
\hline Einkorn-20 & 38.9 & 498.9 & 3669.1 & 3239.1 \\
\hline Einkorn-21 & 91.4 & 780.6 & 1045.3 & 3871.4 \\
\hline Average & 52.6 & 655.8 & 1302.5 & 3712.3 \\
\hline Standard error & 5.1 & 66.1 & 255.6 & 229.4 \\
\hline Median & 41.8 & 581.7 & 706.5 & 3315.1 \\
\hline Standard deviation & 23.3 & 303.0 & 1171.3 & 1051.2 \\
\hline Kurtosis & -1.1 & 6.6 & -0.1 & 1.6 \\
\hline Skewness & 0.6 & 2.2 & 1.2 & 1.4 \\
\hline Min & 27.7 & 369.1 & 343.1 & 2493.0 \\
\hline Max & 96.5 & 1706.1 & 3669.1 & 6571.2 \\
\hline
\end{tabular}


Table 3. Concentrations of microminerals in the einkorn (siyez)

\begin{tabular}{|c|c|c|c|c|c|}
\hline \multirow{2}{*}{ Sample code } & \multicolumn{5}{|c|}{ Concentration of microminerals (mg kg-1) } \\
\hline & $\mathrm{Fe}$ & $\mathrm{Zn}$ & $\mathrm{Mn}$ & $\mathrm{Cr}$ & $\mathrm{Cu}$ \\
\hline Einkorn-1 & 712.40 & 28.05 & 30.01 & 0.70 & 0.58 \\
\hline Einkorn-2 & 37.70 & 34.89 & 22.02 & 0.30 & 3.49 \\
\hline Einkorn-3 & 93.30 & 49.77 & 39.64 & 0.37 & 0.97 \\
\hline Einkorn-4 & 1834.90 & 50.86 & 62.83 & 5.46 & 2.53 \\
\hline Einkorn-5 & 35.90 & 39.59 & 24.06 & 0.33 & 0.15 \\
\hline Einkorn-6 & 140.10 & 32.82 & 29.90 & 1.76 & 0.30 \\
\hline Einkorn-7 & 36.70 & 25.76 & 22.99 & 0.67 & 0.14 \\
\hline Einkorn-8 & 35.40 & 16.45 & 20.22 & 0.11 & 0.47 \\
\hline Einkorn-9 & 37.50 & 33.66 & 24.23 & 0.52 & 0.30 \\
\hline Einkorn-10 & 36.80 & 23.50 & 28.49 & 0.30 & 0.09 \\
\hline Einkorn-11 & 37.20 & 23.95 & 23.34 & 0.27 & 0.17 \\
\hline Einkorn-12 & 36.20 & 30.14 & 29.79 & 0.22 & 0.20 \\
\hline Einkorn-13 & 35.50 & 43.50 & 24.68 & 0.28 & 0.08 \\
\hline Einkorn-14 & 37.90 & 42.03 & 40.51 & 0.52 & 0.81 \\
\hline Einkorn-15 & 38.10 & 26.39 & 22.43 & 0.27 & 0.61 \\
\hline Einkorn-16 & 39.02 & 30.86 & 24.29 & 0.18 & 0.08 \\
\hline Einkorn-17 & 40.70 & 50.18 & 29.47 & 0.48 & 0.12 \\
\hline Einkorn-18 & 38.90 & 30.12 & 20.29 & 0.15 & 0.45 \\
\hline Einkorn-19 & 39.70 & 45.81 & 27.02 & 0.20 & 0.07 \\
\hline Einkorn-20 & 38.30 & 28.92 & 25.02 & 0.50 & 0.42 \\
\hline Einkorn-21 & 126.80 & 34.68 & 29.55 & 1.10 & 0.20 \\
\hline Average & 167.10 & 34.38 & 28.61 & 0.70 & 0.58 \\
\hline Standard error & 89.38 & 2.11 & 2.08 & 0.25 & 0.19 \\
\hline Median & 38.10 & 32.82 & 25.02 & 0.33 & 0.30 \\
\hline Standard deviation & 409.58 & 9.66 & 9.52 & 1.15 & 0.86 \\
\hline Kurtosis & 15.28 & -0.70 & 8.21 & 16.16 & 7.25 \\
\hline Skewness & 3.83 & 0.30 & 2.61 & 3.89 & 2.71 \\
\hline Min & 35.40 & 16.45 & 20.22 & 0.11 & 0.07 \\
\hline Max & 1834.90 & 50.86 & 62.83 & 5.46 & 3.49 \\
\hline
\end{tabular}

Table 4. Comparison of the average concentration of macrominerals with the literature values

\begin{tabular}{l|ccccc}
\multirow{2}{*}{ Wheat type/Origin } & \multicolumn{3}{c}{ Concentration $\left(\mathrm{mg} \mathrm{kg}^{-1}\right)$} & Reference \\
\cline { 2 - 4 } & $\mathrm{Ca}$ & $\mathrm{K}$ & $\mathrm{Mg}$ & $\mathrm{Na}$ & Gabrovská et al. 2002 \\
Einkorn/Czech & 290 & 3940 & 1310 & 18 & Suchowilska et al. 2012 \\
Einkorn/Poland & 420 & 4290 & 1630 & 7 & Abdel-Aal et al. 1995 \\
Einkorn/Canada & - & 3900 & - & - & Rachoń et al. 2014 \\
Einkorn/Poland & 690 & 4890 & 1490 & - & Daelemans et al. 2019 \\
Einkorn/ Belgium & 570 & 5715 & 1516 & 106 & Bâlint et al. 2001 \\
Einkorn/Hungary & 540 & - & 1434 & - & Daelemans et al. 2019 \\
Emmer/Belgium & 423 & 5308 & 1671 & 143 & Zengin, 2015 \\
Emmer/(Turkey) & - & 1630 & 380 & - & Gabrovská et al. 2002 \\
Emmer/Czech & 260 & 3730 & 1300 & 71 & Gabrovská et al. 2002 \\
Buckwheat/Czech & 200 & 4550 & 2060 & 28 & Gabrovská et al. 2002 \\
Spelt/Czech & 280 & 2810 & 1170 & 29 & Abdel-Aal et al. 1995 \\
Spelt/Canada & - & 3750 & - & - & Ertop and Atasoy (2019) \\
Durum/Turkey & 479 & 4770 & 1119 & 26 & Rachoń et al. 2014 \\
Durum/Poland & 600 & 4390 & 1170 & - & Daelemans et al. 2019 \\
Wheat/Belgium & 371 & 4448 & 1300 & 26 & This study \\
Einkorn (siyez)/Turkey & 1303 & 3712 & 656 & 53 & \\
\hline
\end{tabular}

As can be seen form Table 3, microminerals are ranked as iron $(\mathrm{Fe})>\operatorname{zinc}(\mathrm{Zn})>$ manganese $(\mathrm{Mn})>$ chromium $(\mathrm{Cr})>$ copper $(\mathrm{Cu})$ according to their average concentration values. The concentrations of $\mathrm{Fe}$ analyzed in the siyez samples varied from 35.4 to $1834.9 \mathrm{mg} \mathrm{kg}^{-1}$ with an average of $167.1 \mathrm{mg} \mathrm{kg}^{-1}$. The highest concentration of $\mathrm{Fe}$ is analyzed in the Einkorn- 4 while the lowest activity concentration is analyzed in the Einkorn-8. The average Fe content of the siyez samples investigated is significantly higher than the Fe content analyzed in einkorn, emmer, spelt, buckwheat, durum and other wheat samples grown in different countries. The concentrations of $\mathrm{Zn}$ analyzed in the siyez samples varied from 16.5 to $50.9 \mathrm{mg} \mathrm{kg}^{-1}$ with an average of $34.4 \mathrm{mg} \mathrm{kg}^{-1}$. The highest concentration of $\mathrm{Zn}$ is analyzed in the Einkorn- 4 while the lowest activity concentration is analyzed in the Einkorn-8. 
Table 5. Comparison of the average concentration of microminerals with the literature values

\begin{tabular}{l|ccccc}
\multirow{2}{*}{\multicolumn{1}{c}{ Wheat type/Origin }} & \multicolumn{3}{c}{ Concentration $\left(\mathrm{mg} \mathrm{kg}^{-1}\right)$} & & \multirow{2}{*}{ Reference } \\
\cline { 2 - 5 } & $\mathrm{Mn}$ & $\mathrm{Fe}$ & $\mathrm{Cu}$ & $\mathrm{Zn}$ & Suchowilska et al. 2012 \\
Einkorn/Poland & 28 & 49 & 4 & 53 & Gabrovská et al. 2002 \\
Einkorn/Czech & 34 & 29 & - & 42 & Abdel-Aal et al. 1995 \\
Einkorn/Canada & 44 & - & 6 & - & Rachoń et al. 2 \\
Einkorn/Poland & 55 & 54 & 4 & 66 & Bâlint et al. 2001 \\
Einkorn/Hungary & - & 41 & 6 & 35 & Daelemans et al. 2019 \\
Einkorn/Belgium & - & 41 & 6 & 46 & Çakmak et al. 2000 \\
Einkorn/Israel & - & 48 & - & 56 & Gabrovská et al. 2002 \\
Emmer/Czech & 29 & 36 & - & 40 & Zengin, 2015 \\
Emmer/Turkey & 32 & 46 & - & 34 & Daelemans et al. 2019 \\
Emmer/Belgium & - & 61 & 7 & 38 & Tekin et al., 2018 \\
Emmer/Turkey & 18 & 42 & 3 & 17 & Gabrovská et al. 2002 \\
Spelt/Czech & 28 & 29 & - & 31 & Abdel-Aal et al. 1995 \\
Spelt/Canada & 37 & - & - & - & Ertop and Atasoy (2019) \\
Durum/Turkey & - & 28 & 6 & - & Çakmak et al. 2000 \\
Durum/Israel & - & 32 & - & 31 & Çakmak et al. 2000 \\
Durum/Turkey & - & 39 & - & 26 & Tekin et al., 2018 \\
Durum/Turkey & 30 & 37 & 14 & 3 & Gabrovská et al. 2002 \\
Buckwheat/Czech & 17 & 23 & - & 28 & Daelemans et al. 2019 \\
Wheat/Belgium & - & 44 & 5 & 33 & This study \\
Einkorn (siyez)/Turkey & 29 & 167 & 0.6 & 34 &
\end{tabular}

Table 6. Pearson's correlation coefficient for mineral concentrations

\begin{tabular}{|c|c|c|c|c|c|c|c|c|c|}
\hline elements & $\mathrm{Na}$ & $\mathrm{Mg}$ & $\mathrm{Ca}$ & $\mathrm{K}$ & $\mathrm{Fe}$ & $\mathrm{Zn}$ & $\mathrm{Mn}$ & $\mathrm{Cr}$ & $\mathrm{Cu}$ \\
\hline $\mathrm{Na}$ & 1.0 & & & & & & & & \\
\hline $\mathrm{Mg}$ & 0.4 & 1.0 & & & & & & & \\
\hline $\mathrm{Ca}$ & 0.3 & 0.4 & 1.0 & & & & & & \\
\hline $\mathrm{K}$ & 0.5 & 0.9 & 0.4 & 1.0 & & & & & \\
\hline $\mathrm{Fe}$ & 0.3 & 0.7 & 0.5 & 0.5 & 1.0 & & & & \\
\hline $\mathrm{Zn}$ & 0.6 & 0.6 & 0.1 & 0.5 & 0.3 & 1.0 & & & \\
\hline $\mathrm{Mn}$ & 0.5 & 0.9 & 0.5 & 0.9 & 0.8 & 0.6 & 1.0 & & \\
\hline $\mathrm{Cr}$ & 0.3 & 0.8 & 0.5 & 0.7 & 0.9 & 0.4 & 0.8 & 1.0 & \\
\hline $\mathrm{Cu}$ & 0.1 & 0.4 & 0.2 & 0.3 & 0.5 & 0.3 & 0.4 & 0.5 & 1.0 \\
\hline
\end{tabular}

The average $\mathrm{Zn}$ content of the siyez samples investigated is higher than the $\mathrm{Zn}$ content analyzed in emmer (Turkey), spelt (Czech), Durum (Turley, Israel), buckwheat and wheat (Belgium) while it is lower than those analyzed in einkorn (Poland, Czech, Canada, Hungary, Israel, and Belgium), emmer (Czech, and Belgium). The concentrations of Mn analyzed in the siyez samples varied from 20.2 to $62.8 \mathrm{mg} \mathrm{kg}^{-1}$ with an average of $28.6 \mathrm{mg} \mathrm{kg}$. The highest concentration of $\mathrm{Mn}$ is analyzed in the Einkorn-4 while the lowest activity concentration is analyzed in the Einkorn-8. The average Mn content of the siyez samples investigated is higher than the Mn content analyzed in einkorn (Poland), emmer (Turkey), spelt (Czech), and buckwheat (Belgium) while it is lower than those analyzed in einkorn (Czech, Canada), spelt (Canada), and drum (Turkey). The concentrations of $\mathrm{Cr}$ analyzed in the siyez samples varied from 0.1 to $5.5 \mathrm{mg}$ $\mathrm{kg}^{-1}$ with an average of $0.7 \mathrm{mg} \mathrm{kg}$. The highest concentration of $\mathrm{Cr}$ is analyzed in the Einkorn- 4 while the lowest activity concentration is analyzed in the Einkorn-8. The concentrations of $\mathrm{Cu}$ analyzed in the siyez samples varied from 0.1 to $3.5 \mathrm{mg} \mathrm{kg}^{-1}$ with an average of $0.6 \mathrm{mg}$ $\mathrm{kg}^{-1}$. The highest concentration of $\mathrm{Cu}$ is analyzed in the Einkorn-2 while the lowest activity concentration is analyzed in the Einkorn-19. The average $\mathrm{Cu}$ content of the siyez samples investigated is significantly lower than the $\mathrm{Cu}$ content analyzed in einkorn, emmer, spelt, buckwheat, durum and other wheat samples grown in different countries.

The Pearson coefficients for the relationship between the macro- and microminerals analyzed in the einkorn (siyez) samples are given in Table 6 in which bold value indicates significant correlation at $\mathrm{P} \leq 0.05$. It can be observed from Table 6 that strong positive correlation coefficients are obtained for the following minerals: $\mathrm{Mg}$ vs. $\mathrm{K}(0.9), \mathrm{Fe}(0.7), \mathrm{Mn}(0.9)$ and $\mathrm{Cr}(0.8)$; K vs. $\mathrm{Mn}(0.9)$ and $\mathrm{Cr}$ (0.7); Fe vs. $\mathrm{Mn}$ (0.8) and $\mathrm{Cr}(0.9)$; Mn vs. $\mathrm{Cr}$ (0.8).

\section{Conclusions}

The literature comparison revealed that the investigated siyez samples are richer in terms of $\mathrm{Ca}$ and $\mathrm{Fe}$ contents compared to einkorn, emmer, spelt, buckwheat, and durum wheat samples grown in different countries and Turkey.

\section{References}

Abdel-Aal ESM, Hucl P, Sosulski FW. 1995. Compositional and nutritional characteristics of spring einkorn and spelt wheats. Cereal Chemistry, 72:621-624.

Abugoufa AHA, Turhan S, Kurnaz A, Karataşlı M. 2020. Determination of essential and toxic elements content of Turkish peanut and assessment of health risk, International Journal of Environmental Analytical Chemistry, doi: $10.1080 / 03067319.2020 .1763329$ 
Adamu HM, Mshelia EH, Maigari AU, Umar HY, Balogun OL. 2016. Determination of some trace elements and macro minerals in Grewia Mollis plant parts. International Journal of Pure and Applied Science Research, 11(2):1-16.

Atak M. 2017. Buğday ve Türkiye buğday köy çeşitleri. Journal of Agricultural Faculty of Mustafa Kemal University, 22:7188.

Bâlint AF, Kovâcs G, Erdei L, Sutka J. 2001. Comparison of the $\mathrm{Cu}, \mathrm{Zn}, \mathrm{Fe}, \mathrm{Ca}$ and $\mathrm{Mg}$ contents of the grains of wild, ancient and cultivated wheat species. Cereal Research Communications, 29:375-382.

Brandolini A, Hidalgo A, Moscaritolo S. 2008. Chemical composition and pasting properties of einkorn (Triticum monococcum L. subsp. monococcum) whole meal flour. Journal of Cereal Science, 47:599-609.

Çakmak I, Özkan H, Braun HJ, Welch RM, Romheld V. 2000. Zinc and iron concentrations in seeds of wild, primitive, and modern wheats. Food and Nutrition Bulletin, 21:401-403.

Daelemans L, De Leyn I, Camerlinck M, Raes K, Vermeir P, Van Bockstaele F. 2019. Nutritional properties of ancient wheats available on the Belgian market. 19th ICC conference, Science meets technology, Vienna, Austria.

Emeksizoğlu B. 2016. The investigation of some quality properties of einkorn (Triticum monococcum L.) wheat cultivated in Kastamonu and it using in noodles and bazlama. $\mathrm{PhD}$ Thesis. Ondokuz Mayis University, Graduate School of Natural and Applied Sciences. Samsun.

Erba D, Hidalgo A, Brescianni J, Brandolini A. 2011. Environmental and genotypic influences on trace element and mineral concentrations in whole meal flour of einkorn (Triticum monococcum L. subsp. monococcum). Journal of Cereal Science, 54:250-254.

Ertop MH, Atasoy R. 2019. Comparison of physicochemical attributes of einkorn wheat (Triticum monococcum) and durum wheat (Triticum durum) and evaluation of morphological properties using scanning electron microscopy and image analysis. Journal of Agricultural Sciences, 25:9399.

Gabrovská D, Fiedlerova V, Holasova M, Masckova E, Smrcinov H, Winterova R, Michalova A, Hutar M. 2002. The nutritional evaluation of underutilized cereals and buckwheat. Food and Nutrition Bulletin, 23:246-253.

Khan ZI, Ahmad K, Rehman S, Siddique S, Bashir H, Asma ZA, Sohail M, Ali SA, Cazzato E, De Mastro G. 2017. Health risk assessment of heavy metals in wheat using different water qualities: implication for human health. Environmental Science and Pollution Research, 24:947-955.

Kurnaz A, Mutlu E, Uncumusaoğlu AA. 2016. Determination of water quality parameters and heavy metal content in surface water of Çiğdem Pond (Kastamonu/Turkey). Turkish Journal of Agriculture-Food Science and Technology, 4(10): 907913.

Løje A, Møller B, Laustsen AM, Hansen A. 2003. Chemical composition, functional properties and sensory profiling of einkorn (Triticum monococcum L.). Journal of Cereal Science, 37:231-240.

McKevith B. 2004. Nutritional aspects of cereals. Nutrition Bulletin, 29:111-142.

Mutlu E, Demir T, Kutlu B, Yanık T. 2013. Determination of Water Quality Parameters in Sivas - Kurugöl Lake, Turkish Journal of Agriculture - Food Science and Technology, 1(1): $37-43$
Mutlu E, Uncumusaoğlu AA. 2016. Physicochemical Analysis of Water Quality of Brook Kuruçay. Turkish Journal of Agriculture - Food Science and Technology, 4(11): 991-998.

Mutlu E, Kutlu B, Demir T. 2016. Assessment of Çinarli Stream (Hafik-Sivas)'S Water Quality via Physico-Chemical Methods, Turkish Journal of Agriculture-Food Science and Technology, 4(4): 267-278

Mutlu E, Kurnaz A. 2017. Determination of seasonal variations of heavy metals and physicochemical parameters in Sakiz Pond (Kastamonu-Turkey). Fresenius Environmental Bulletin, 26(4): 2806-2815.

Mutlu E. 2019. Evaluation of spatio-temporal variations in water quality of Zerveli stream (northern Turkey) based on water quality index and multivariate statistical analyses. Environmental Monitoring and Assesment, June 2019, 191:33

Özkan H, Brandolini A, Torun A, Altintas S, Eker S, Kilian B, Braun H, Salamini F, Cakmak I. 2007. Natural variation and identification of microelements content in seeds of einkorn wheat (Triticum monococcum). Wheat Production in Stressed Environments. Proceedings of the 7th International Wheat Conference, 455-462, New York.

Rachoń L, Szumiło G, Brodowska M, Woźniak A. 2014. Nutritional value and mineral composition of grain of selected wheat species depending on the intensity of a production technology. Journal of Elementology, 20(3):705715.

Soetan KO, Olaiya CO, Oyewole OE. 2010. The importance of mineral elements for humans, domestic animals and plants: A review. African Journal of Food Science, 4(5): 200-222.

Suchowilska E, Wiwart M, Kandler W, Krska R. 2012. A comparison of macro-and microelement concentration in the whole grain of flour Triticum species. Plant Soil and Environment, 58:141-147.

Sultan DAO, Turhan Ş, Kurnaz A, Hançerlioğulları A, Kamberli AK, Emeksizoğlu B. 2020. Investigation of natural radionuclide and essential metal contents of ancient wheat einkorn (Triticum monococcum L.) grown in Turkey. Radiochimica Acta, 108(12):999-1007.

Şenoğlu T. 2019. The relationship between ancient wheat species and human health. Master of Thesis. Yildiz Technical University, Institute of Science. Istanbul.

Tekin M, Cengiz MF, Abbasov M, Aksoy A, Canci H, Akar T. 2018. Comparison of some mineral nutrients and vitamins in advanced hulled wheat lines. Cereal Chemistry, 95: 436-444.

Zengin G. 2015. A research on determination of quality parameters of some ancient wheat. Master of Thesis, Selçuk University Institute of Science. Konya.

Zhang Y, Yin C, Cao S, Cheng L, Wu G, Guo J. 2018. Heavy metal accumulation and health risk assessment in soil-wheat system under different nitrogen levels. Science of the Total Environment, 622:1499-1508

Zhao FJ, Su YH, Dunham SJ, Rakszegi M, Bedo Z, McGrath SP, Shewry PR. 2009. Variation in mineral micronutrient concentrations in grain of wheat lines of diverse origin, Journal of Cereal Science, 49:290-295. 